mgr inz. Damian Goliwąs

dr inz. Marian Kaluba prof. IPS

mgr inz. Mateusz, Stęchlicki

Instytut Pojazdów Szynowych ,TABOR”

\title{
Passenger alarm system for passenger train
}

The article presents the concept of the PAS system, which is a combination of the passenger emergency brake system with the system ensuring the possibility of driver's voice communication with the person submitting the danger. The functional requirements for the system are given, the architecture of the proposed solutions and areas of their cooperation with other vehicle on-board systems such as the voice communication system CFA are described. The compatibility of solutions both with the pneumatic brake UIC and other modern types of brakes with an safety electric loop are taken into account in considerations.

\section{System alarmu pasażera dla pociągów pasażerskich}

W artykule przestawiono koncepcje systemu PAS, będqcego połaczeniem uktadu hamulca bezpieczeństwa pasażera z ukladem zapewniajacym możliwość komunikacji głosowej maszynisty z osobq zglaszajaca niebezpieczeństwo. Podano wymagania funkcjonalne dla systemu, opisano architekture proponowanych rozwiqzań oraz obszary ich wspótpracy z innymi pokładowymi systemami pojazdu takimi jak układ komunikacji głosowej CFA. W rozważaniach uwzględniono kompatybilność rozwiqzania zarówno z hamulcem pneumatycznym UIC jak $i$ innymi nowoczesnymi typami hamulców z elektrycznq pętla bezpieczeństwa.

\section{Wstęp}

System PAS (ang. Passenger Alarm System) jest rozwiązaniem łączącym w sobie cechy hamulca bezpieczeństwa pasażera z możliwością wysyłania żądania hamowania, mostkowania już wdrożonego procesu oraz układu komunikacji głosowej maszynistapasażer. System ten jest kolejnym krokiem rozszerzającym możliwości świadomej reakcji ze strony maszynisty na niebezpieczeństwo powstałe $\mathrm{w}$ przestrzeni pasażerskiej.

Rozwiązania techniczne umożliwiające maszyniście pociagu podjęcie reakcji na uruchomienie przez pasażera hamowania bezpieczeństwa zostały po raz pierwszy przedstawione w 1997 roku w karcie UIC 541-5 [6]. Karta ta opisywała układ zdolny do tzw. mostkowania hamulca bezpieczeństwa pasażera, dzięki czemu maszynista zyskał możliwość decydowania o miejscu zatrzymania się pociagu, której wcześniej był pozbawiony. Rozwiązanie to przyczyniło się w znacznym stopniu do poprawy bezpieczeństwa w szczególności pojazdów poruszających się na liniach dużych prędkości i/lub przebiegających częściowo $\mathrm{w}$ tunelach, na mostach czy wiaduktach. W przypadku zatrzymania pociagu $\mathrm{w}$ takich miejscach bardzo utrudnione jest prowadzenie skutecznej ewakuacji pasażerów oraz działania ratownicze.

\section{Introduction}

PAS system (eng. Passenger Alarm System) is a solution that combines the features of the passenger emergency brake with the possibility of sending a request for braking, bridging already implemented process and system of voice communication driverpassenger. This system is the next step in expanding the possibilities of conscious reaction from the driver to the danger arising in the passenger compartment.

Technical solutions, making the train driver to take response to starting the emergency braking by the passenger, were first presented in 1997 in the UIC 541-5 [6]. This card described the system capable of so-called bridging of the passenger emergency brake, allowing the driver to gain the opportunity to decide on the place to stop the train, which was previously deprived. This solution contributed significantly to the improvement of safety in the particular vehicles riding on high speed lines and/or running partly in tunnels, on bridges or viaducts. In the case of stopping of a train in such places it is very difficult to conduct the effective evacuation of passengers and the rescue operations.

In 2009, the European standard concerning the requirements for the subsystem of emergency brake appeared. It was expected that it would consist of 
W 2009 roku pojawiła się europejska norma dotycząca wymagań dla podsystemu hamulca bezpieczeństwa. Przewidywano, że będzie składać się z części dotyczących: wymagań ogólnych, systemu pneumatycznego, elektropneuma-tycznego, mostkowania hamowania bezpieczeństwa oraz mostkowania w przypadku łączenia różnych pojazdów ze sobą. Opublikowano jedynie część pierwszą dotyczącą wymagań ogólnych, natomiast pozostałe zostały zaniechane ze względu na pojawienie się nowego rozwiązania $\mathrm{w}$ postaci zastosowania żądania uruchomienia hamowania.

Nowe rozwiązanie wprowadziło pewne warunki, które decydowały o tym, czy pasażer w określonej sytuacji może uruchomić hamowanie bezpośrednio, czy jedynie wysłać takie żądanie do maszynisty a ten z kolei zadecydować o jego zasadności. Rozwiązanie to (NBA) zostało opracowane i opisane w karcie UIC 541-6 [7] w 2010 roku. Wprowadzono w nim warunkowe działanie hamulca bezpieczeństwa $\mathrm{w}$ zależności od miejsca w którym znajduje się pociag - w obszarze peronu hamulec jest uruchamiany bez zwłoki natomiast na szlaku, zanim proces hamowania zostanie zapoczątkowany maszynista zostaje powiadomiony o alarmie i ma możliwość zadecydowania o jego zasadności.

W 2014 roku ukazała się europejska norma PN-EN 16334 wprowadzająca pojęcie Systemu Alarmu Pasażera. System ten jest rozwinięciem układu NBA z karty UIC 541-6 [7]. Norma odchodzi od klasycznie rozumianej definicji „hamulca bezpieczeństwa pasażera" wprowadzając pojęcie „alarmu pasażera”. Kierunkiem rozwoju w tym przypadku jest dalsze ograniczenie bezpośredniego wpływu pasażera na bieg pociagu.

Możliwość komunikowania się $\mathrm{z}$ personelem pokładowym pociagu może również zostać wykorzystana $\mathrm{w}$ celach niezwiązanych $\mathrm{z}$ bezpieczeństwem ruchu pociągu. W tym celu wprowadzono pojęcie układu CFA (ang. Call For Aid) umożliwiającego nawiązanie połączenia $\mathrm{z}$ obsługą o niższym priorytecie niż $\mathrm{w}$ przypadku systemu PAS. Wyposażenie pojazdu $\mathrm{w}$ taki system jest zasadne szczególnie w przypadku gdy skład pociagu obsługuje jedynie maszynista. Zaleca się również zastosowanie rozwiązań CFA w miejscach przeznaczonych do korzystania przez osoby $\mathrm{z}$ niepełnosprawnością (toalety, drzwi z podjazdami itp.).

System PAS jest dzisiaj standardem dla nowych i modernizowanych zespołów trakcyjnych. Poniżej przedstawiono wymagania stawiane systemowi PAS oraz proponowany przez IPS sposób realizacji zagadnienia, zapewniający zgodność z wymaganiami m.in. TSI oraz aktualnych norm europejskich.

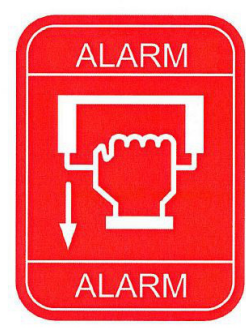

Rys. 1 - Etykieta urządzenia PAD [3]

Fig. 1 - Label of PAD device [3]

parts concerning: general requirements, a pneumatic system, an electro-pneumatic system, a bridging of emergency braking and bridging when joining the different vehicles together. Only the first part was published, relating to general requirements, while others were abandoned due to appearance of a new solution in the form of application of request to start the braking.

The new solution introduced the certain conditions that decided whether a passenger in a given situation can start braking immediately, or only send such a request to the driver and he, in turn, decide on the validity. This solution (NBA) was developed and described in UIC 541-6 [7] in 2010. It introduced a conditional operation of emergency brake depending on the place where the train is - in the area of the platform the brake is activated without delay while on the route, before the braking process is initiated, the driver is informed of the alarm and has the possibility to decide on the validity.

In 2014, the European standard EN 16334 appeared, introducing the concept Alarm Passenger System. This system is an extension of the NBA system from the UIC 541-6 [7]. The standard departs from the classical understanding the definition of " passenger emergency brake " introducing the concept of "passenger alarm". Direction of development in this case is further limiting the direct impact of a passenger on the train.

The possibility of communication with the crew of the train it can also be used for purposes unrelated to traffic safety of the train. For this purpose, the concept of the CFA system was introduced (eng. Call For Aid) allowing the connection with the service with a lower priority than the PAS system. Vehicle equipment in such a system is justified especially when the train is operated only by the driver. It is also recommended to use the solutions CFA in places intended for use by the people with disabilities (toilets, doors with ramps, etc.).

The PAS system is now standard for new and modernized traction units. The system requirements given the PAS system and the proposed by IPS method of realization of this issue, ensuring the compliance with the requirements, among others TSI and the current European standards, are presented below. 


\section{System PAS - wymagania ogólne}

W październiku 2014 roku, PKN zatwierdził europejską normę EN 16334 jako polską, zastępując jednocześnie normę PN-EN 15327-1 zatytułowaną „Podsystem hamulca bezpieczeństwa”. Dokument ten ukazuje czym jest System Alarmu Pasażera (w skrócie PAS),jakie urządzenia można do niego zaliczyć oraz w jaki sposób powinny one realizować swoje zadania. Podstawowe założenia, do których przewidziane jest użycie systemu PAS to:

- umożliwienie pasażerom pociagu, w sytuacji zagrożenia, poinformowanie maszynisty o niebezpieczeństwie;

- umożliwienie maszyniście, w momencie alarmu, kontunuowania ruchu pociagu lub zatrzymanie go w bezpiecznym, w ocenie maszynisty, miejscu;

- uruchomienie automatycznego hamowania pociagu $\mathrm{w}$ przypadku, gdy niebezpieczeństwo pojawiło się $\mathrm{w}$ obszarze peronu lub $\mathrm{w}$ przypadku kiedy maszynista nie podejmuje żadnej reakcji na alarm.

Realizacja wyżej wymienionych zadań wymaga zabudowy na pojeździe urządzeń zarówno dla maszynisty jak i pasażera. W skład systemu PAS można zaliczyć następujące główne elementy podstawowe:

a) interfejs pasażera PAI (ang. Passenger Alarm Interface) - jest to zespół urządzeń w przestrzeni pasażerskiej zabudowanych obok siebie lub jedno urządzenie wyposażone w elementy niezbędne do realizacji zadań systemu PAS tj.:

- urzadzenie PAD - jest urządzeniem dzięki któremu pasażer ma możliwość zasygnalizowania niebezpieczeństwa najczęściej poprzez pociagnięcie specjalnej rękojeści $\mathrm{w}$ dół. PAD powinien również przesłać pasażerowi informację zwrotną w postaci wizualnej o jego zadziałaniu. Urządzenie to powinno być oznaczone etykietą oraz posiadać możliwość przywrócenia do pierwotnego stanu po uruchomieniu za pomocą klucza kwadratowego. Przykład takiego urządzenia pokazano na rysunku 2 .

- interkom / interfejs CFA - jest urządzeniem zapewniającym możliwość komunikacji głosowej pasażera $\mathrm{z}$ maszynistą. Jego wyposażenie stanowią elementy takie jak kontrolki sygnalizacyjne, głośnik mikrofon oraz przycisk.. Jeżeli pojazd jest wyposażony w układ CFA to ten panel spełnia

- instrukcje i etykiety informacyjne - pełnią funkcję identyfikującą oraz wskazują miejsce zabudowy urządzenia. Etykietę oznaczającą urządzenie PAD prezentuje rysunek 1 .

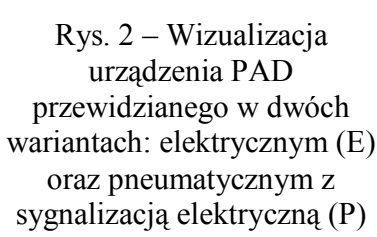

Fig. 2 - Visualization of PAD device anticipated in two versions: electric(E) and pneumatic with electric signalling $(\mathrm{P})$

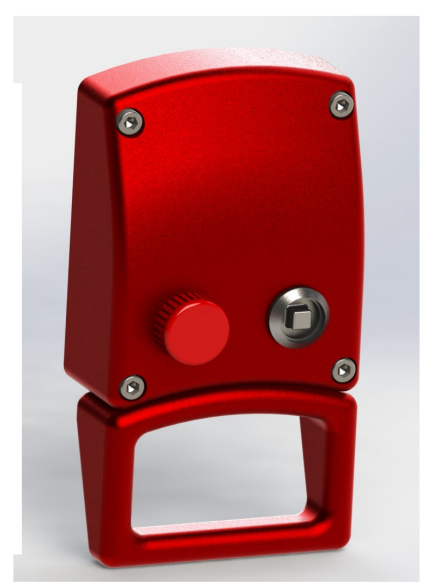

\section{PAS system - general requirements}

In October 2014 the PKN approved the European standard EN 16334 as Polish, at the same time replacing the PN-EN 15327-1 titled "Subsystem of emergency brake". This document shows what the Passenger Alarm System (abbreviated as PAS), which devices can be included to it and how they should carry out their tasks. The basic assumptions, which is expected to use the PAS system to, are:

- enable the train passengers in a dangerous situation to inform the driver about the danger;

- enable the driver at the time of the alarm to continue or stop a moving train in a safe place, in the view of the driver;

- start the automatic braking of the train in the case when there was a danger in the area of platform or when the driver does not take any response to alarm.

Realization of the above mentioned tasks requires the installation on a vehicle of devices for both the driver and passenger. The PAS system may include the following main elements:

a) passenger interface PAI (eng. Passenger Alarm Interface) - is a set of devices in the passenger area built - in next to each other or one device equipped with the necessary elements to perform the tasks of PAS system, i.e.:

- PAD device - is a device by which the passenger has the possibility to signal danger, most often by pulling a special handle down. PAD should also send the feedback in the visual form on its start working to the passenger. This device should be labeled and have the possibility to restore to its original state after starting using a square wrench. An example of such a device is shown in Figure 2.

- CFA intercom/interface - is a device that provides the possibility to voice communication of the passenger with the driver. Its equipment includes the elements such as the signal indicator lights, speaker, microphone and button. If the vehicle is equipped with a CFA system, 
b) urządzenia zabudowane w kabinie maszynisty są to elementy zapewniające możliwość współpracy systemu $\mathrm{z}$ maszynista poprzez elementy zabudowane na pulpicie maszynisty lub $\mathrm{w}$ innych dostępnych miejscach. $Z$ grupy tych urządzeń można wyszczególnić m.in.:

- modut kabinowy PAS - jest urządzeniem, które wywołuje alarm w kabinie maszynisty na skutek uruchomienia przez pasażera urządzenia PAD. Poza informacją o pociagnięciu za rękojeść do tego modułu docierają również sygnały $\mathrm{z}$ podukładu detekcji peronu, sygnały ze sterownika systemu komunikacji oraz $\mathrm{z}$ przycisku reakcji/mostkowania. Moduł ten steruje również pracą kontrolek uruchomionych urządzeń PAD zapewniających informację zwrotną dla pasażera o reakcji maszynisty na alarm.

- modut komunikacyjny - jest urządzeniem dzięki któremu maszynista ma możliwość zarządzania połączeniami głosowymi. Możliwe jest określenie miejsca $\mathrm{w}$ pociagu w którym zauważono niebezpieczeństwo oraz kolejkowanie rozmówców w zależności od priorytetu wezwania.

- interfejs maszynisty - są to zespoły zabudowane na pulpicie mające za zadanie umożliwienie maszyniście podjęcia reakcji na alarm przez naciśnięcie przycisku reakcji/mostkowania, nawiązania połączenia głosowego lub wdrożenia hamowania pociągu. Interfejsem tym może być $m$. in. manipulator hamulca zespolonego oraz panel sterowania systemem komunikacji. Moduł kabinowy PAS posiada wejścia $\mathrm{z}$ wszystkich urządzeń będących interfejsem pomiędzy maszynistą a pojazdem oraz wyjścia sterujące np. pracą kontrolek alarmowych czy głośników alarmujących maszynistę o zagrożeniu.

System PAS uzależnia swoją reakcję na uruchomienie alarmu przez pasażera od miejsca $\mathrm{w}$ jakim znajduje się pociagg. Rozróżnić można trzy sytuacje a mianowicie: postój na peronie, odjazd z peronu oraz bieg pociagu pomiędzy stacjami. Sposób działania systemu uwzględniający te zależności przedstawia tabela 1 .

Powyżej wymieniono główne elementy architektury oraz algorytmy systemu PAS realizujące wymagane zadania. Sposób realizacji tych zadań może odbywać się dwojako - poprzez zastosowanie wyłącznie sygnałów elektrycznych lub $\mathrm{z}$ zastosowaniem dodatkowych obwodów pneumatycznych. W przypadku wyboru wariantu elektrycznego, Instytut Pojazdów Szynowych „TABOR” proponuje rozwiązanie PAS E przeznaczone do współpracy z elektryczną pętlą bezpieczeństwa pojazdu. Rozwiązanie to zostało opisane w punkcie 4 . Kiedy pojazd nie jest wyposażony w elektryczną pętlę bezpieczeństwa pojazdu lub this panel fulfills a dual role - provides communication in the case of danger and the possibility to provide information not directly related to the safety of the train service. More information on the CFA is in Chapter 3.

- instructions and information labels identify and indicate the place of installation of the device. The label indicating PAD device is shown in Figure 1.

b) devices installed in the driver's cab - these are the elements ensuring the possibility of cooperation of the system with the driver by built-in on the driver desk or in other accessible places. From the group of these devices it can be detailed among other things:

- PAS cab module - is a device that triggers an alarm in the driver's cab as a result of starting up PAD deice by the passenger. Apart from the information to pull the handle, the signals from the subsystem of platform detection, the signals from the controller of communication system and from the response/bridging button reach to this module. This module also controls the operation of indicator lights of starting PAD devices providing feedback for a passenger on a driver's response to an alarm.

- communication module - is a device by which the driver has the possibility to manage the voice calls. It is possible to determine the place in the train where the danger and queuing of callers depending on the priority of the call is noticed.

- driver's interface - are sets built in the desk whose task is enabling the driver to take the response to the alarm by pressing the reaction/bridging button, to start the voice call or to implement the train braking. This interface can be, among other thing, the manipulator of continous brake and the communication system control panel. The PAS cab module has inputs from all devices that are the interface between the driver and the vehicle, and control outputs, e.g. work of alarm indicator lights or speakers alarming the driver about the danger.

The PAS system makes its response to starting alarm by the passenger conditional on the place in which there is the train. It can be distinguished three situations, namely: stop at the platform, the departure from the platform and the riding of the train between the stations. The way of the system operation taking account of these relations is presented in Table 1.

The above the main elements of architecture and algorithms of PAS system performing the required tasks are listed. The way of realization of these tasks can be done with two ways - by using only electrical 


\begin{tabular}{|c|c|c|}
\hline $\begin{array}{c}\text { Sytuacja } \\
\text { pociągu/Train } \\
\text { situation }\end{array}$ & $\begin{array}{c}\text { Odpowiedź system na } \\
\text { uruchomienie przez } \\
\text { pasażera urządzenia } \\
\text { PAD/Response of system to } \\
\text { starting PAD device by } \\
\text { passenger }\end{array}$ & $\begin{array}{l}\text { Możliwe sposoby reakcji maszynisty/personelu pokladowego/ } \\
\text { Possible ways of reaction of the driver/ board crew }\end{array}$ \\
\hline $\begin{array}{c}\text { Postój na stacji z } \\
\text { odryglowanymi } \\
\text { drzwiami/Stop at } \\
\text { the station with } \\
\text { the not bolted } \\
\text { door }\end{array}$ & $\begin{array}{l}\text { 1. Hamowanie awaryjnel } \\
\text { Emergency braking } \\
\text { 2. Żadanie połaczenia } \\
\text { gtosowego/ Request for a } \\
\text { voice call }\end{array}$ & $\begin{array}{l}\text { 1. Maszynista - rozmowa z pasażerem poprzez CFA/ The driver - a } \\
\text { conversation with a passenger by CFA } \\
\text { 2. Obshuga - po zażegnaniu niebezpieczeństwa, przywrócenie } \\
\text { uruchomionej rękojeści PAD do pierwotnej pozycji/ Service - after } \\
\text { preventing the danger, the restoration of started PAD handle to its } \\
\text { original position } \\
\text { 3. Maszynista - kontynuowanie biegu pociagu/The driver- } \\
\text { continuation of train riding }\end{array}$ \\
\hline $\begin{array}{l}\text { Odjazd ze stacji } \\
\text { po zamknięciu i } \\
\text { zaryglowaniu } \\
\text { drzwi/ Departure } \\
\text { from the station } \\
\text { after closing and } \\
\text { bolting the door }\end{array}$ & $\begin{array}{l}\text { 1. Hamowanie awaryjne/ } \\
\text { Emergency braking } \\
\text { 2. Żadanie połaczenia } \\
\text { głosowego/ Request for a } \\
\text { voice call } \\
\text { 3. Po zatrzymaniu pociagu } \\
\text { możliwośc mostkowania } \\
\text { hamowania bezpieczeństwa/ } \\
\text { After stopping the train it is } \\
\text { possibility to bridge the } \\
\text { emergency braking }\end{array}$ & $\begin{array}{l}\text { 1. Maszynista - rozmowa z pasażerem poprzez CFA/ The driver - a } \\
\text { conversation with a passenger by CFA } \\
\text { 2. Maszynista - po zatrzymaniu się pociagu pojawia się możliwość } \\
\text { mostkowania hamowania bezpieczeństwa/ The driver - after } \\
\text { stopping of the train there is the possibility of bridging the safety } \\
\text { braking } \\
\text { 3. Maszynista - w razie konieczności przemieszczenie pociagu na } \\
\text { zmostkowanym hamulcu bezpieczeństwa w celu zatrzymania w } \\
\text { odpowiednim miejscu, likwidacji zagrożenia i/lub otwarcia drzwi } \\
\text { pojazdu/ The driver - if it is necessary to move the train at the } \\
\text { bridged emergency brake to stop in the right place, eliminate the } \\
\text { danger and/or opening the vehicle door } \\
\text { 4. Obstuga - po zażegnaniu niebezpieczeństwa, przywrócenie } \\
\text { uruchomionej rękojeści PAD do pierwotnej pozycji/ Service - after } \\
\text { preventing the danger, the restoration of started PAD handle to its } \\
\text { original position } \\
\text { 5. Maszynista-kontynuowanie biegu pociagu/ The driver- } \\
\text { continuation of train riding }\end{array}$ \\
\hline $\begin{array}{c}\text { Bieg pociągu } \\
\text { pomiędzy } \\
\text { stacjami/ Riding } \\
\text { of the train } \\
\text { between the } \\
\text { stations }\end{array}$ & $\begin{array}{l}\text { 1. Wywolanie alarmu } w \\
\text { kabinie maszynisty/Trigger the } \\
\text { alarm in driver's cab } \\
\text { 2. Żadanie potaczenia } \\
\text { glosowego/ Request for a } \\
\text { voice call } \\
\text { 3. Oczekiwanie na reakcje } \\
\text { maszynisty w czasie } t<10 \mathrm{~s} \text {./ } \\
\text { Waiting for the driver's } \\
\text { reaction for } t<10 \mathrm{~s} \text {. } \\
\text { 4. W przypadku braku reakcji } \\
\text { - hamowanie awaryjne/ In the } \\
\text { absence of reaction - } \\
\text { emergency braking }\end{array}$ & $\begin{array}{l}\text { 1. Maszynista - podjecie jakiejkolwiek reakcji: przycisk, rozmowa z } \\
\text { pasażerem poprzez CFA, wdrożenie hamowania awaryjnego/ The } \\
\text { driver - take any reaction: button, talk with the passenger by the } \\
\text { CFA, implementation of emergency braking } \\
\text { 2. Maszynista - kontynuowanie biegu pociagu z aktywnym alarmem } \\
\text { jeżeli sytuacja nie wymaga nagłego zatrzymania się lub } \\
\text { zatrzymanie pociagu w odpowiednim miejscu w celu likwidacji } \\
\text { zagrożenia/ The driver - continuation riding of the train with an } \\
\text { active alarm if the situation does not require a sudden stop or train } \\
\text { stop in the right place to eliminate the danger } \\
\text { 3. Obstuga - po zażegnaniu niebezpieczeństwa, przywrócenie } \\
\text { uruchomionej rękojeści PAD do pierwotnej pozycji/ Service - after } \\
\text { preventing the danger, the restoration of started PAD handle to its } \\
\text { original position } \\
\text { 4. Maszynista -kontynuowanie biegu pociagu/ The driver- } \\
\text { continuation of train riding }\end{array}$ \\
\hline
\end{tabular}

z jakiś powodów wymagane jest zachowanie minimalnej funkcjonalności przy braku zasilania to proponuje się rozwiązanie PAS P opisane w punkcie 5. W tabeli 2 porównano obydwa warianty wskazując na główne różnice pomiędzy tymi rozwiązaniami.

Aby możliwe było spełnienie wymagań normy [4] rozwiązania opisane powyżej należy zintegrować z układem komunikacji głosowej. Układ ten może funkcjonować jako dedykowane rozwiązanie dla PAS lub w postaci układu CFA, który został opisany w punkcie 3 . signals or using the additional pneumatic circuits. When an electrical variant is selected the Rail Vehicles Institute "TABOR" proposes a solution of PAS E intended for cooperation with an electric loop of vehicle safety. This solution is described in section 4. When the vehicle is not equipped with an electric loop of vehicle safety or for some reasons it is required to keep the minimum functionality at a lack of power, it is proposed the solution of PAS P described in section 5. In Table 2 two variants are compared pointing to the main differences between these solutions. 
Tab. 2 -Porównanie proponowanych przez IPS wariantów systemu PAS / Comparison of proposed by the IPS variants of PAS system

\begin{tabular}{|c|c|c|}
\hline & $\begin{array}{c}\text { PAS E } \\
\begin{array}{c}\text { System Alarmu Pasażera - wariant } \\
\text { elektryczny/ Passenger Alarm System - } \\
\text { electric variant }\end{array}\end{array}$ & $\begin{array}{c}\text { PAS P } \\
\text { System Alarmu Pasażera - wariant } \\
\text { pneumatyczny z sygnalizacją elektryczną/ } \\
\text { Passenger Alarm System - pneumatic variant } \\
\text { with electric signalling }\end{array}$ \\
\hline $\begin{array}{c}\text { Inicjowanie hamowania } \\
\text { bezpieczeństwa/ } \\
\text { Initiating emergency } \\
\text { braking }\end{array}$ & $\begin{array}{l}\text { Poprzez przerwanie elektrycznej petli } \\
\text { bezpieczeństwa pociagu/ By breaking the } \\
\text { electrical loop of train safety }\end{array}$ & $\begin{array}{l}\text { Poprzez odpowietrzenie przewodu głównego/ By } \\
\text { venting the main pipe }\end{array}$ \\
\hline $\begin{array}{c}\text { Przewidywane } \\
\text { warianty/ Predicted } \\
\text { variants }\end{array}$ & $\begin{array}{l}\text { 1. Pętla bezpieczeństwa przebiega przez } \\
\text { urzadzenia PAD (rys. } 4 \text { i rys. 5)/Safety loop } \\
\text { runs through the PAD devices (Fig. } 4 \text { and Fig. } \\
\text { 5) } \\
\text { 2. Pętla bezpieczeństwa jest przerywana na } \\
\text { skutek przerwania pętli alarmowej (rys. 6)/ The } \\
\text { safety loop is broken as a result of breaking of } \\
\text { the alarm loop (Fig. 6) }\end{array}$ & $\begin{array}{l}\text { 1. Zawór hamowania nagłego mostkowany jest } \\
\text { przez sterownik do którego docieraja informacje } \\
\text { o przerwaniu pettli alarmowej/ Emergency brake } \\
\text { valve bridged by a controller to which the } \\
\text { information about breaking of the alarm loop } \\
\text { reaches } \\
\text { 2. Zawór hamowania nagłego mostkowany jest } \\
\text { przez sterownik do którego docieraja informacje } \\
\text { o zmianach rezystancji obwodów hamulca } \\
\text { bezpieczeństwa (rozwiqzanie NBA [8]/ } \\
\text { Emergency brake valve bridged by a controller to } \\
\text { which the information about changes of } \\
\text { resistance of the emergency brake circuits, (NBA } \\
\text { solution [8]reaches }\end{array}$ \\
\hline \multirow{4}{*}{ Uwagi/ Comments } & $\begin{array}{l}\text { Dzięki przesyłaniu sygnałów wytacznie droga } \\
\text { elektryczna nie ma potrzeby doprowadzania } \\
\text { przewodów pneumatycznych do przedziałowych } \\
\text { urzadzeń PAD/By sending signals only } \\
\text { electronically there is no need to lead the } \\
\text { pneumatic pipes to the compartment PAD } \\
\text { devices.. }\end{array}$ & $\begin{array}{l}\text { Urzadzenie PAD realizuje funkcję hamulca } \\
\text { bezpieczeństwa w sposób klasyczny (rys. 8) } \\
\text { dlatego konieczne jest podtaczenie pneumatyczne } \\
\text { do każdego z urzadzen PAD./ PAD device } \\
\text { performs the function of the emergency brake in a } \\
\text { conventional manner (Fig. 8), so it is necessary to } \\
\text { connect pneumatically to each of PAD devices }\end{array}$ \\
\hline & $\begin{array}{l}\text { Pociag powinien być wyposażony w elektryczna } \\
\text { pętlę bezpieczeństwa./ The train should be } \\
\text { equipped with an electrical safety loop. }\end{array}$ & $\begin{array}{l}\text { Pociag może nie posiadać elektrycznej pętli } \\
\text { bezpieczeństwa./ The train may not have the } \\
\text { electrical safety loop. }\end{array}$ \\
\hline & $\begin{array}{l}\text { Lokalne moduly hamulcowe nie musza być } \\
\text { wyposażone w zawór hamowania nagłego } \\
\text { wspótpracujacy z urzadzeniami PAD./ Local } \\
\text { brake modules do not have to be equipped with } \\
\text { emergency brake valve cooperating with the } \\
\text { PAD devices. }\end{array}$ & $\begin{array}{l}\text { Lokalne moduly hamulcowe należy wyposażyć w } \\
\text { zawory hamowania nagłego obstugujace } \\
\text { urzqdzenia PAD./ Local brake modules must be } \\
\text { equipped with emergency braking valves } \\
\text { servicing the PAD device. }\end{array}$ \\
\hline & $\begin{array}{l}\text { System działa jeżeli pojazd posiada zasilanie } \\
\text { energia elektrycznq./ The system works if the } \\
\text { vehicle has an electric power supply }\end{array}$ & $\begin{array}{l}\text { W przypadku zaniku zasilania elektrycznego, } \\
\text { system realizuje funkcję hamulca bezpieczenstwa } \\
\text { droga pneumatycznq (bez możliwości } \\
\text { mostkowania)./ In the case of electric supply } \\
\text { failure, the system performs the function of the } \\
\text { emergency brake with the pneumatic way (without } \\
\text { bridging). }\end{array}$ \\
\hline Zastosowanie & $\begin{array}{l}\text { Rozwiazanie odpowiednie dla nowych } i \\
\text { modernizowanych zespotów trakcyjnych./ The } \\
\text { solution suitable for new and modernized } \\
\text { traction units. }\end{array}$ & $\begin{array}{l}\text { Rozwiqzanie odpowiednie dla wagonów } \\
\text { osobowych i modernizowanych zespotów } \\
\text { trakcyjnych./ Solution suitable for passenger cars } \\
\text { and modernized traction units. }\end{array}$ \\
\hline
\end{tabular}

\section{Urządzenie do wzywania pomocy i komunikacji}

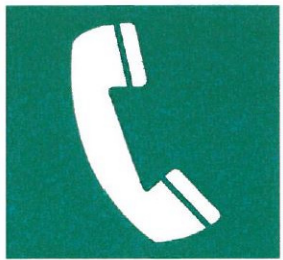

In order to meet the requirements of the standard [4] the solutions described above should be integrated with the system of voice communication. This system can function as a dedicated solution for the PAS or in the form of the CFA system which is described in point 3 .

\section{Device to call for aid and communication}

In February 2016 it was issued the Polish standard 
W lutym 2016 ukazała się polska norma [5] opisująca nowy układ określany jako CFA (ang. Call For Aid). CFA pełni funkcję informacyjną niezwiązaną z bezpieczeństwem ruchu pociagu $\mathrm{w}$ przeciwieństwie do systemu PAS. Zadaniem tego układu jest poinformowanie obsługi pociagu o potrzebie udzielenia pomocy pasażerowi w postaci informacji bądź asysty W wykonaniu pewnej czynności np. pomoc osobie z niepełnosprawnością opuścić pojazd. Rozróżnia się dwie sytuacje eksploatacyjne w których pociąg obsługiwany jest przez różną liczbę obsługi. W przypadku kiedy poza maszynistą obsługą pociagu zajmuje się również inna osoba system CFA nie powinien sygnalizować maszyniście oczekującego połączenia. Zadanie obsługi systemu CFA spoczywa wówczas na pozostałych członkach załogi którzy z dedykowanych paneli komunikacyjnych moga przeprowadzić rozmowę $\mathrm{z}$ pasażerem. W przypadku gdy pociag jest obsługiwany wyłączenie przez maszynistę sygnalizacja o oczekującym połączeniu powinna zostać przekazana do kabiny. Należy zwrócić uwagę iż systemy PAS oraz CFA posiadają wspólne elementy w swojej infrastrukturze dlatego bezwzględny priorytet nadaje się połączeniom głosowym aktywowanym na skutek pociagnięcia rękojeści PAD.

Interfejsem pasażera jest panel komunikacyjny wyposażony w głośnik, lampki sygnalizacyjne mikrofon oraz przycisk. Interfejs ten powinien znajdować się przy każdym z urządzeń PAD zabudowanych w pojeździe. Oznacza to w praktyce że taki interkom powinien znajdować się w każdej wydzielonej przestrzeni dostępnej dla pasażerów w pociągu.

\section{Zarys wariantu PAS E}

Zastosowanie rozwiązania, w którym do urządzenia PAD znajdującego się $\mathrm{w}$ przestrzeni pasażerskiej nie jest konieczne prowadzenie przewodów pneumatycznych jest bardzo korzystne pod względem technologicznym. Jednakże pewną niedogodnością takiego sposobu jest brak możliwości korzystania z systemu hamulca bezpieczeństwa $\mathrm{w}$ przypadku gdy pociag należy odholować na skutek jego awarii, której konsekwencją jest m.in. brak możliwości zasilenia pojazdu w energię elektryczną. Przy czym należy podkreślić iż niedogodność ta nie wpływa na poziom bezpieczeństwa a jedynie na zakres jego funkcjonalności.

W opisywanym wariancie system PAS może funkcjonować w 3 trybach z czego 2 są trybami awaryjnymi o ograniczonej funkcjonalnością mianowicie:

- Tryb operacyjny (wszystkie podsystemy sprawne) - w tym trybie maszynista ma dostęp do pełnej funkcjonalności systemy zgodnie z wymaganiami normy [3]
[5] describing a new system known as CFA (eng. Call For Aid). CFA serves as an information function unrelated to traffic safety of the train unlike the PAS system. The purpose of this system is to inform train staff about the need to give the passenger aid in the form of information or as an assistance in the execution of certain activity e.g. help a person with a disability to leave the vehicle. There are two operational situations in which the train is operated by a different number of staff. In case when apart the driver of the train, service of the train is also involved in another person, CFA system should not indicate to the driver the waiting call. The task of service of the CFA system rests then on the other members of the crew who from the dedicated communications panel can have a conversation with a passenger. When the train is operated solely by the driver the signalling about the waiting call should be sent to the cabin. It should be noted that PAS and CFA systems have the common elements in their infrastructure, so the absolute priority is given to the voice calls activated as a result of pulling the PAD handle.

Passenger interface is a communication panel equipped with a speaker, indicator lights, microphone and button. This interface should be at each of PAD devices built-in the vehicle. This means in practice that such an intercom should be in each separate space accessible for the passengers in the train.

\section{Outline of PAS E variant}

Application of a solution, in which the to the PAD device located in the passenger compartment it is not necessary to carry the pneumatic pipes, is very advantageous in terms of technology. However, one inconvenience of this method is impossibility to use the emergency brake system when a train must be towed as a result of failure, the consequence of which includes the lack of supply electricity to the vehicle. In addition it must be emphasized that this inconvenience does not affect the level of safety and only the scope of its functionality.

In the described variant, the PAS system can operate in 3 modes, 2 of which are the emergency modes with limited functionality, namely:

- Operating mode (all subsystems are efficient) - in this mode the driver has access to the full functionality of systems in accordance with the requirements of standard [3]

- Emergency Mode with a request for emergency braking (communication subsystem is inactivated or damaged) - in this mode the emergency brake operates according to the principle of the NBA [7] 
- Tryb awaryjny z żądaniem hamowania bezpieczeństwa (podsystem komunikacyjny dezaktywowany lub uszkodzony) - w tym trybie hamulec bezpieczeństwa działa zgodnie z zasadą działania NBA [7]

- Tryb awaryjny z możliwością mostkowania hamowania bezpieczeństwa (podsystem detekcji peronu dezaktywowany lub uszkodzony) - w tym trybie sterownik systemu PAS zostaje wyłączony a maszynista ma możliwość mostkowania hamowania bezpieczeństwa w klasyczny sposób zgodnie z regułami NBU [6]

Istnieje wiele sposobów umożliwiających wykonanie powyższych założeń, np. zintegrowanie pętli alarmowej z pętlą bezpieczeństwa. Poniżej przedstawiono trzy przykładowe rozwiązania, które system PAS integrują z pętlą bezpieczeństwa pojazdu.

Mostkowanie odbywać się może poprzez połączenie zasilania do przewodu sygnałowego w aktywnej kabinie maszynisty, tak jak na rysunku 4. Rozwiązanie to ma jednak pewną wadę. Zerwanie pociagu $\mathrm{w}$ momencie, którym mostko-wanie jest aktywne, spowoduje otwarcie zaworów upustowych jedynie w części bez aktywnej kabiny maszynisty. Pozostałe zawory po stronie kabiny aktywnej będą otwierane $\mathrm{z}$ pewną zwłoką zależną od tempa spadku ciśnienia w przewodzie głównym. Niewątpliwą zaletą tego rozwiązania jest prostota i niski koszt ze względu na minimalną ilość przewodów. Możliwe zastosowanie tego typu układu, to krótkie zespoły trakcyjne lub autobusy szynowe.

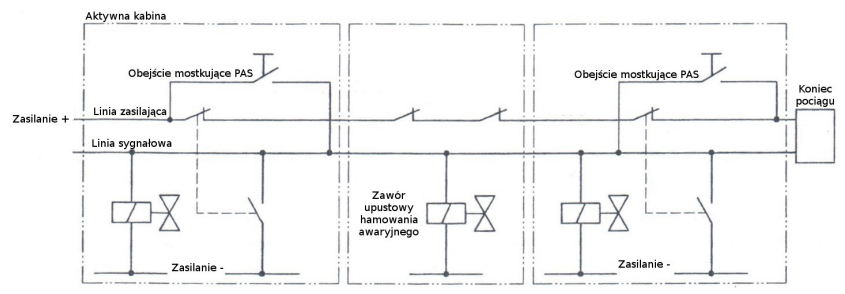

Rys. 4 - Przykładowy schemat pętli bezpieczeństwa zintegrowanej z PAS wg PN-EN 16185-1 [2]

Fig. 4 - Exemplary diagram of safety loop integrated with PAS under PN-EN 16185-1 [2]

W takim przypadku, alternatywą może być mostkowanie obwodów urządzeń PAD, dla każdego z członów indywidualnie, tak jak na rysunku 5. Rozwiązanie to zapewnia, iż proces mostkowania nie ma wpływu na możliwość pozostawienia zaworów upustowych zasilonych, pomimo przerwania pętli bezpieczeństwa. Dla tego rozwiązania konieczne jest prowadzenie wzdłuż pociagu dodatkowego przewodu sterującego pracą przełączników, na każdym z członów pociaggu. Dodatkowo, na każdym z członów wyposażonych w urządzenie PAD, konieczne jest.
- Emergency Mode with bridgeable of emergency braking (subsystem of platform detection is inactivated or damaged) - in this mode the controller of PAS system is switched off and the driver has the opportunity to bridging the emergency braking in the classic manner in accordance with the rules of the NBU [6]

There are many ways to perform the above assumptions e.g. integration of the alarm loop with the safety loop. Below, three examples of solutions that integrate PAS system with the vehicle safety loop, are presented.

Bridging can be carried out with a connection of power to the signal wire in the active driver's cab as it is shown in Fig.4. This solution, however, has a fault. Breaking the train at the moment, when the bridging is active, will open the release valves only in the part without the active driver's cab. Other valves on the side of the active cab will be opened with some delay depending on the rate of pressure drop in the main pipe. An undoubted advantage of this solution is the simplicity and low cost due to the minimal number of pipes. The possible use of this type of system is short traction units and rail buses.

In this case the bridging of PAD devices circuits can be an alternative, for each of elements individually, as it is shown in Figure 5. This solution ensures that the bridging process does not affect the possibility of leaving the powered release valves despite the breaking the safety loop. For this solution it is necessary to carry along the train the additional wire controlling the operation of switches, on each of the elements of the train. Additionally, on each of the elements equipped with the PAD device it is necessary to make the by-passes and building-in of the switch. The significant advantage of this solution it is the possibility of an emergency disconnection of the individual elements consisting in manual and fixed bridging within one element which allows, in the event of a local failure, to keep the functionality of the other elements - the solution is particularly advantageous for the long traction units. The disadvantage of this solution is, as in the previous solution, that the bridging of PAS brake disconnects the PAD devices from the loop and it should be carried the next circuit, which is independent on the safety loop, to the signalling of handle pulling along the train.

Another of the possible solutions for using is to isolate the safety loop and the PAS alarm loop. This solution is universal i.e. the PAS cab controller can works with the safety loop of the vehicle or the main pipe by the release. As a result of this, it is possible to apply the electrical PAS alarm loop in the absence of electrical safety loop in the vehicle. Next advantage of the described solution is that at the time of 
utworzenie obejścia i zabudowa przełącznika. Istotną przewaga tego rozwiązania jest możliwość awaryjnego odłączenia poszczególnych członów polegające na manualnym i stałym mostkowaniu $\mathrm{w}$ obrębie jednego członu, które umożliwia, w wypadku lokalnej awarii, zachować funkcjonalność w pozostałych członach - rozwiązanie szczególnie korzystne dla długich zespołów trakcyjnych. Wadą tego rozwiązania jest to, że podobnie jak w poprzednim rozwiązaniu, mostkowanie hamulca PAS odłącza urządzenia PAD od pętli i do sygnalizacji pociagnnięcia rękojeści należy prowadzić wzdłuż pociagu kolejny, niezależny od pętli bezpieczeństwa, obwód.

Kolejnym z możliwych do zastosowania rozwiązań jest wyodrębnienie pętli bezpieczeństwa oraz pętli alarmowej PAS. Rozwiązanie to jest uniwersalne to znaczy że sterownik kabinowy PAS może współpracować z pętlą bezpieczeństwa pojazdu lub z przewodem głównym poprzez zawór upustowy dzięki czemu możliwe jest zastosowanie elektrycznej pętli alarmowej PAS przy braku elektrycznej pętli bezpieczeństwa $\mathrm{w}$ pojeździe. Kolejną zaletą opisywanego rozwiązania jest to iż $\mathrm{w}$ momencie mostkowania pętla alarmowa pełni funkcję pętli sygnałowej PAS sygnalizującej użycie urządzenia PAD. Rozwiązanie to jest uniwersalne i odpowiednie dla każdego typu pojazdu wyposażonego w elektryczną pętlę bezpieczeństwa. Schemat opisywanego rozwiązania przedstawiono na rysunku 6.

Zawory upustowe realizujące odpowietrzenie przewodu głównego w momencie zaniku napięcia w pętli mogą być umieszczone na każdym z członów (tak jak na powyższych rysunkach) lub tylko w członach skrajnych pojazdu.

Powyższe przykłady opisują wyłącznie sposób integracji systemu PAS z elektryczną pętlą bezpieczeństwa pojazdu, dzięki czemu spełnione są wymagania normy PN-EN 16334 oraz wymagań TSI [6]. Ogólny, całościowy schemat systemu PAS przedstawia rysunek 7, w którym uwzględniono integrację z systemem komunikacji głosowej oraz interfejsami pasażera oraz maszynisty. Schemat ten jest zgodny $\mathrm{z}$ wymienionymi wcześniej sposobami połączenia $\mathrm{z}$ pętlą bezpieczeństwa.

W opisywanym rozwiązaniu, urządzenie PAD wysyła sygnały wyłącznie $\mathrm{w}$ postaci elektrycznej dlatego nie ma konieczności prowadzenia przewodów pneumatycznych do tego urządzenia (patrz tabela 2). Zabudowa urządzenia jest prosta dzięki czemu również dostęp do prac serwisowych został w znacznym stopniu poprawiony. Urządzenie PAD (rys. 2) jest montowane na ścianie za pomocą 4 śrub M6 (możliwość ukrycia śrub poprzez montaż od wewnątrz).

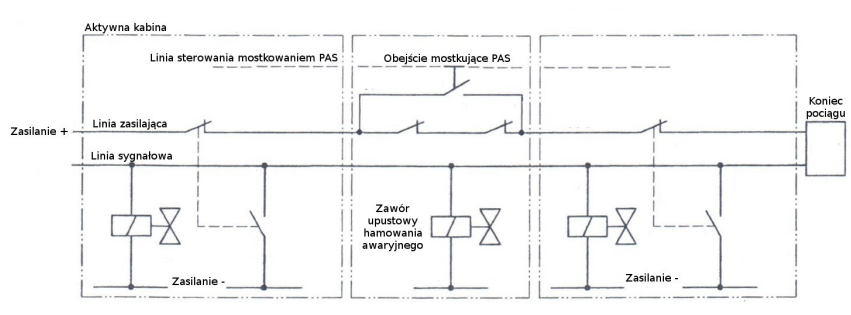

Rys. 5 - Przykładowy schemat alternatywnego rozwiązania pętli bezpieczeństwa zintegrowanej z PAS

Fig. 5 - Exemplary diagram of alternative solution of safety loop integrated with PAS

bridging the alarm loop acts as a PAS signal loop signalling the use of the PAD device. This solution is universal and suitable for each type of vehicle equipped with the electrical safety loop. The diagram of the described solution is presented in Figure 6.

The release valves realizing the venting of the main pipe at the time of power failure in the loop can be placed on each of the elements (as it is shown in the above drawings) or only in extreme elements of the vehicle.

The above examples describe only the way to integrate the PAS system with an electric safety loop of the vehicle. As a result of this the requirements of PN-EN 16334 and the requirements of the TSI [6] are fulfilled. The general, overall diagram of the PAS system is shown in Figure 7, which contains the integration with the voice communication system and interfaces of passenger and driver. This diagram is in conformity with the previously mentioned methods of connection with the safety loop.

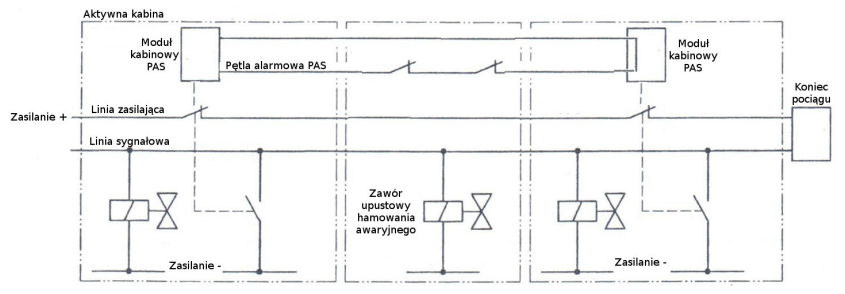

Rys. 6 - Przykładowy schemat rozwiązania pętli bezpieczeństwa współpracującej z pętlą alarmową PAS

Fig. 6 - Exemplary diagram of solution of safety loop working with PAS alarm loop

In the described solution the PAD device sends signals only in the electric form, so there is no need to carry the pneumatic pipes to this device (see Table 2 ). Installation of the device is simple, so the access to the service works is improved in significant degree. PAD device (Fig. 2) is mounted on the wall with 4 screws M6 (the possibility of hiding the screws by the mounting from the inside). 


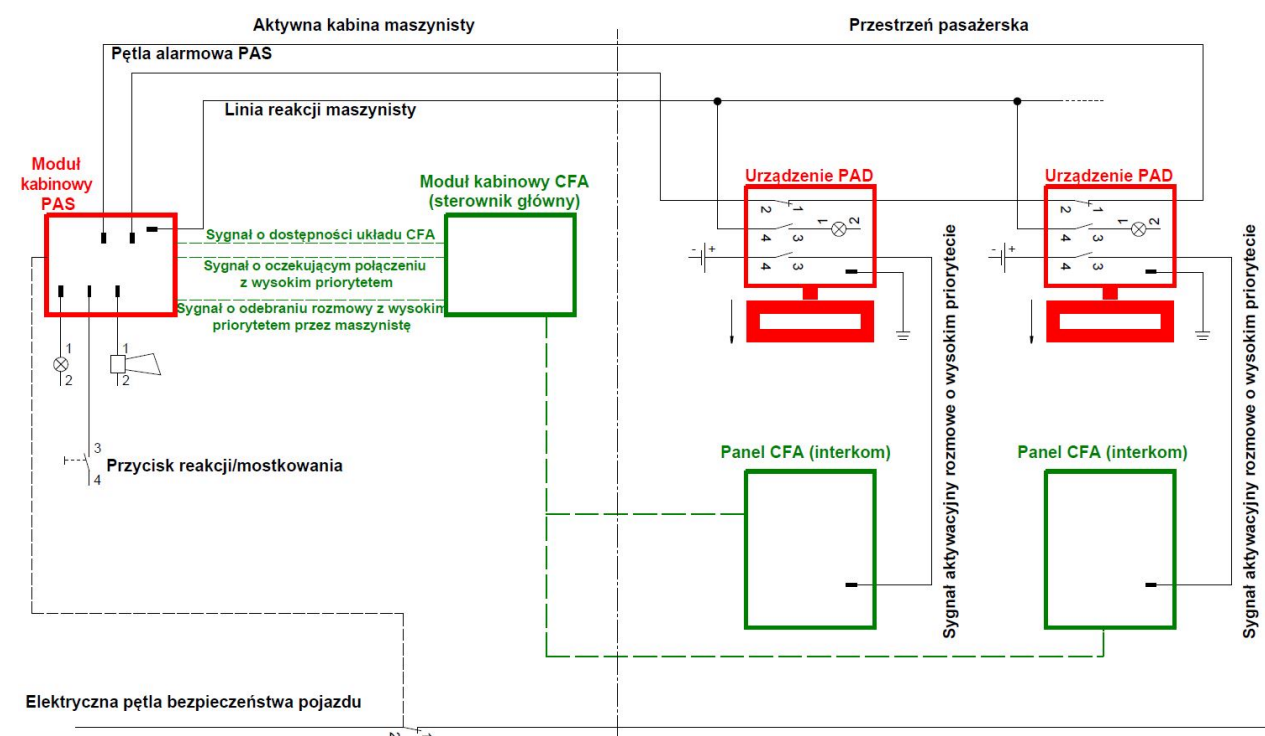

Rys. 7 -

Uproszczony schemat

systemu PAS

dla trzeciego

wariantu

współpracy z

EBL

Fig. 7 -

Simplified

diagram of

PAS system

for the third

variant of

working with

EBL

\section{Zarys wariantu PAS $P$}

System PAS P jest rozwiązaniem, w którym urządzenie PAD wyposażone jest $\mathrm{w}$ pneumatyczny zawór upustowy zapewniający możliwość opróżnienia przewodu głównego, przy braku zasilania na pojeździe. Głównym zastosowaniem dla tego typu systemu są pociagi prowadzone przez lokomotywę [1], aczkolwiek może on być zastosowany również na modernizowanych zespołach trakcyjnych nie posiadających elektrycznej pętli bezpieczeństwa lub w zespołach trakcyjnych, dla których wymaga się zachowania minimalnej funkcjonalności przez układ hamulca bezpieczeństwa, przy braku zasilania w energię elektryczną.

Architektura systemu współpracującego z przewodem głównym hamulca automatycznego UIC może różnic się w zależności od charakteru pojazdu. Dla zespołów trakcyjnych zaleca się rozwiązanie oparte na pętli alarmowej przerywanej na skutek pociagnięcia za rękojeść urządzenia $\mathrm{PAD}$, natomiast dla pociągów składających się z wagonów istnieje możliwość oparcia rozwiązań na wymaganiach karty UIC 541-6 [7]. W przypadku zastosowania pętli alarmowej, rozwiązanie to jest modyfikacją przykładu opisanego na rysunku 5. Sterownik nie ingeruje w pętlę bezpieczeństwa pojazdu - zarządza zaworami ep mostkowania na każdym z członów lub wagonów w pociągu. Rozszerzenie o obwody pneumatyczne zostało pokazane na rysunku 8 .

Niezależnie od tego, czy rozwiązanie bazuje na pętli alarmowej, czy też na zasadach NBA [7], system PAS może funkcjonować w 4 trybach, z czego 3 są trybami awaryjnymi o ograniczonej funkcjonalności, mianowicie::

- Tryb operacyjny (wszystkie podsystemy sprawne) - w tym trybie maszynista ma dostęp do pełnej funkcjonalności systemy zgodnie $\mathrm{z}$ wymaganiami normy [3]

\section{Outline of PAS P variant}

The PAS P system is the solution, wherein the PAD device is equipped with a pneumatic release valve ensuring the possibility of emptying the main pipe in the absence of power on the vehicle. The trains leading by a locomotive are mainly used for this type of system [1], although it can be also used in the modernized traction units that do not have electrical safety loop or in the traction units, for which it is required to keep a minimum functionality of the emergency brake system in the absence of electric supply.

The design of the system working with the main pipe of an UIC automatic brake may differ depending on the character of the vehicle. For the traction units it is recommended that the solution was based on the alarm loop broke as a result of pulling the handle of PAD device, but for trains consisting of wagons there is the opportunity to base the solutions on the requirements of UIC 541-6 [7]. When the alarm loop is used, this solution is a modification of the example described in Figure 5. The controller does not interfere in the safety loop of the vehicle - manages the ep valves of bridging on each of the elements or wagons in the train. The extension of the pneumatic circuits is shown in Figure 8.

Regardless of whether the solution is based on the alarm loop or on the principles of the NBA [7], PAS system can operate in four modes, of which three are the emergency modes with the limited functionality, namely:

- Operating mode (all subsystems are efficient) - in this mode the driver has access to the full functionality of systems in accordance with the requirements of standard [3] 
- Tryb awaryjny z żądaniem hamowania bezpieczeństwa (podsystem komunikacyjny dezaktywowany lub uszkodzony) - w tym trybie hamulec bezpieczeństwa działa zgodnie z zasadą działania NBA [7]

- Tryb awaryjny z możliwością mostkowania hamowania bezpieczeństwa (podsystem detekcji peronu dezaktywowany lub uszkodzony) - w tym trybie sterownik systemu PAS zostaje wyłączony a maszynista ma możliwość mostkowania hamowania bezpieczeństwa w klasyczny sposób zgodnie z regułami NBU [6]

- Tryb awaryjny bez możliwości mostkowania hamowania bezpieczeństwa (układ funkcjonuje bez zasilania energia elektryczną poprzez realizując funkcje droga pneumatyczną) - w tym trybie nie ma możliwości wpływu na zainicjowany przez pasażera proces hamowania bezpieczeństwa

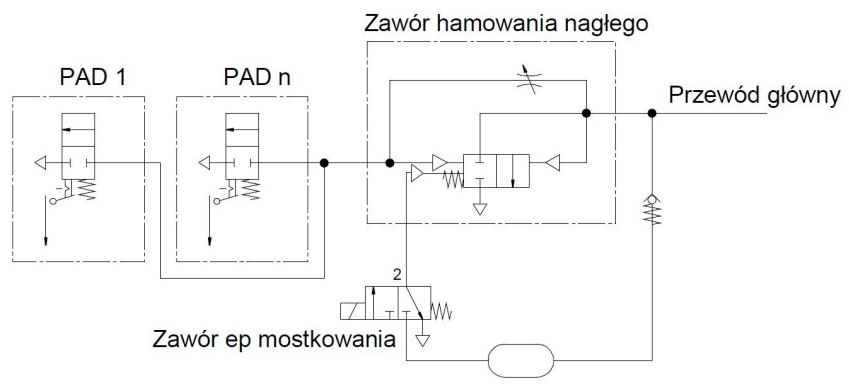

Rys. 8 - Przykładowy schemat obwodów pneumatycznych na członie/wagonie systemu PAS P

Fig. 8 - Exemplary diagram of the pneumatic circuits on the element/wagon of PAS P system

W opisywanym rozwiązaniu, urządzenie PAD wyposażone jest w zawór upustowy (rys. 8), dzięki czemu możliwa jest realizacja hamowania bezpieczeństwa w przypadku braku zasilania (patrz: tabela 2). Pociągnięcie za rękojeść, podobnie jak w wariancie elektrycznym, przerywa pętlę alarmową. Zawór upustowy odpowietrza przewód hamulca bezpieczeństwa i o uruchomieniu hamowania decyduje stan zaworu ep mostkowania (rys. 8). Hamowanie uruchomione jest poprzez otwarcie przewodu głównego do atmosfery na członie/wagonie, w którym uruchomiono urządzenie PAD. Zabudowa urządzenia jest równie prosta co wersji elektrycznej, jednakże połączenie pneumatyczne wymaga zastosowania specjalnego wspornika, do którego z jednej strony podłącza się przewód instalacji hamulca bezpieczeństwa, $\mathrm{z}$ drugiej natomiast urządzenie PAD. Wspornik montowany jest do konstrukcji ściany działowej, a urządzenie PAD montuje się do wspornika. Pomiędzy te dwa elementy można wprowadzić elementy wyłożenia zewnętrznego ściany - w takim wypadku urządzenie
- Emergency Mode with a request for emergency braking (communication subsystem is inactivated or damaged) - in this mode the emergency brake operates according to the principle of the NBA [7]

- Emergency Mode with bridgeable of emergency braking (subsystem of platform detection is inactivated or damaged) - in this mode the controller of PAS system is switched off and the driver has the opportunity to bridging of the emergency braking in the classic manner in accordance with the rules of the NBU [6]

- Emergency Mode without bridgeable of emergency braking (system works without the electric supply by realizing the functions by the pneumatic way) - in this mode, there is no possibility to influence on the process of emergency braking initiated by the passenger

In the described solution the PAD device is equipped with the release valve (Fig. 8). As a result of this it is possible to realize the emergency braking in the case of power failure (see Table 2). Pulling the handle, as in the electric variant, breaks the alarm loop. The release valve vents the emergency brake pipe and the condition of ep valve of bridging decides about starting of the braking (Fig. 8). The braking is started by opening the main pipe to the atmosphere on the element/wagon, in which the PAD device is started. Installation of the device is as simple as the electric version, but the pneumatic connection requires a special bracket, to which on one side the pipe of emergency brake installation is connected, and on the other the PAD device. The bracket is mounted to the structure of the partition wall, and the PAD device is mounted to the bracket. Between these two elements it can be put the elements of lining of the outside wall - in this case the PAD device will press the laminate to the construction of the bracket and the partition wall. The PAD device (Fig. 2) is mounted with 4 screws M6, as well as the bracket (the possibility of hiding the screws of PAD device by installation from inside)

\section{Conclusion}

From the solutions within the emergency passenger brake, today it is required much more than in the past. The driver driving a train equipped with the PAS system, thanks to the voice conversations, obtains the greater conscious of the danger. In the event of occurring the danger he can take decisions appropriate to the danger. Besides the functional requirements of the whole system, the modern design, adjusting to the contemporary trends set by the designers of interiors of passenger vehicles, is 
PAD będzie dociskało laminaty do konstrukcji wspornika i ściany działowej. Urządzenie PAD (rys. 2) jest montowane za pomoca 4 śrub M6, podobnie jak wspornik (możliwość ukrycia śrub urządzenia PAD poprzez montaż od wewnątrz)..

\section{Podsumowanie}

Od rozwiązań z zakresu hamulca bezpieczeństwa pasażera wymaga się dzisiaj znacznie więcej niż przed laty. Maszynista, prowadząc pociąg wyposażony w system PAS, dzięki funkcji rozmów głosowych, zyskuje większą świadomość istniejącego zagrożenia. W sytuacji wystąpienia niebezpieczeństwa może podejmować odpowiednie do zagrożenia decyzje. Poza wymaganiami funkcjonalnymi całego systemu, od urządzenia PAD oczekuje się również nowoczesnego designu, wpasowującego się we współczesne trendy, wyznaczane przez projektantów od wnętrz pojazdów pasażerskich.

Aby możliwe było sprostanie aktualnie obowiązującym wymaganiom z zakresu hamulca bezpieczeństwa pasażera, konieczne było opracowanie koncepcji technicznych dla nowych uwarunkowań oraz zaproponowanie urządzeń odpowiednich do tego typu zastosowań. W ramach prac badawczo rozwojowych wytypowano urządzenie określane jako PAD w dwóch wariantach - wyłącznie elektryczne oraz rozszerzone o elementy pneumatyczne. Przewidziano możliwość zastosowania tego urządzenia zarówno dla zespołów trakcyjnych nowych i modernizowanych oraz na wagonach pasażerskich.

Została zapewniona możliwość integracji z układem komunikacji głosowej funkcjonującym jako odrębny układ CFA. also expected from the PAD device.

In order to meet the currently applicable requirements concerning the passenger emergency brake, it was necessary to develop the technical concepts for new conditions and to propose the devices suitable for such applications. As part of the research and development works it was selected the device known as PAD in two variants - only electric and extended by the pneumatic components. It was predicted the possibility of using of this device for both new and modernized traction units as well as on the passenger wagons.

It was provided the possibility of integration with the voice communication system functioning as a separate CFA system.

\section{Bibliografia Bibliography}

[1] PN-EN 14198 Kolejnictwo. Hamowanie. Wymagania dla systemu hamulcowego pociagów prowadzonych przez lokomotywe.

[2] PN-EN 15327-1 Kolejnictwo. Podsystem hamulca bezpieczeństwa. Część 1: Wymagania ogólne dotyczqce hamulca bezpieczeństwa i urzqdzeń do jego uruchamiania przez pasażera.

[3] PN-EN 16185-1 Kolejnictwo. Systemy hamulcowe wieloczłonowych zespołów trakcyjnych. Część 1: Wymagania i definicje.

[4] PN-EN 16334 Kolejnictwo. System ręcznego hamulca bezpieczeństwa $w$ pociagach pasażerskich. Wymagania dotyczace systemu.

[5] PN-EN 16683 Kolejnictwo. Urzqdzenie do wzywania pomocy i komunikacji. Wymagania

[6] Rozporzqdzenie Komisji (UE) nr 1302/2014 z dnia 18 listopada 2014 r. $w$ sprawie technicznej specyfikacji interoperacyjności odnoszqcej się do podsystemu „Tabor - lokomotywy $i$ tabor pasażerski" systemu kolei w Unii Europejskiej.

[7] UIC 541-5 Hamulec. Hamulec elektropneumatyczny (hamulec ep). Elektropneumatyczne mostkowanie hamulce bezpieczeństwa.

[8] UIC 541-6 Hamulec. Hamulec elektropneumatyczny (hamulec ep) i żadanie hamowania bezpieczeństwa (NBA) dla pojazdów w pociagach z lokomotywa. 